\title{
TRANSFORMER RATIO DEPENDENCE ON BUNCH LENGTH AT NON-LINEAR WAKEFIELD EXCITATION IN PLASMA BY ELECTRON BUNCH WITH GAUSSIAN CHARGE DISTRIBUTION
}

\author{
D.S. Bondar ${ }^{2}$, I.P. Levchuk ${ }^{1}$, V.I. Maslov ${ }^{1,2}$, I.N. Onishchenko ${ }^{1}$ \\ ${ }^{1}$ NSC Kharkov Institute of Physics \& Technology \\ 61108 Kharkov, Ukraine \\ ${ }^{2}$ Karazin Kharkiv National University \\ 61022, Kharkov, Ukraine \\ e-mail:vmaslov@kipt.kharkov.ua \\ Received March 30, 2018
}

Using $2 \mathrm{~d} 3 \mathrm{v}$ code LCODE, the numerical simulation of nonlinear wakefield excitation in plasma by shaped relativistic electron bunch with charge distribution, which increases according to Gaussian charge distribution up to the maximum value, and then decreases sharply to zero, has been performed. Transformer ratio, as the ratio of the maximum accelerating field to the maximum decelerating field inside the bunch, and accelerating the wakefield have been investigated taking into account nonlinearity of the wakefield. The dependence of the transformer ratio and the maximum accelerating field on the length of the bunch was investigated with a constant charge of the bunch. It was taken into account that the length of the nonlinear wakefield increases with increasing length of the bunch. It is shown that the transformer ratio reaches its maximum value for a certain length of the bunch. The maximum value of the transformer ratio reaches six as due to the profiling of the bunch, and due to the non-linearity of the wakefield.

KEYWORDS: transformer ratio, plasma wakefield, bubble, blowout, wakefield acceleration

\author{
ЗАЛЕЖНІСТЬ КОЕФІЦІЕНА ТРАНСФОРМАЦІЇ ВІД ДОВЖИНИ ЗГУСТКА \\ ЗА ЗБУДЖЕННЯ НЕЛІНІЙНОЇ КІЛЬВАТЕРНОЇ ХВИЛІ У ПЛАЗМІ ЕЛЕКТРОННИМ ЗГУСТКОМ 3 \\ УРАХУВАННЯМ ТОГО, ЩО ЗАРЯД ЗРОСТАЕ ЗА ЗАКОНОМ ГАУСА \\ Д.С. Бондар ${ }^{2}$, І.П. Левчук ${ }^{1}$, В.І. Маслов ${ }^{1,2}$, І.М. Онищенко ${ }^{1}$ \\ ${ }^{I}$ ННЦ Харківський фізико-технічний інститут \\ 61108, Харків, Україна \\ ${ }^{2}$ Харківський національний університет імені В.Н. Каразіна \\ 61022, Харків, Україна
}

Використовуючи код LCODE, проведено 2d3v чисельне моделювання збудження нелінійної кільватерної хвилі в плазмі профільованим релятивістським електронним згустком з щільністю заряду, яка наростає по закону Гауса до максимального значення, а потім різко зменшується до нуля. Коефіцієнт трансформації, як відношення максимального прискорюючого поля до максимального гальмуючого поля всередині згустку, і прискорююче поле досліджені з урахуванням нелінійності кільватерної хвилі. Досліджено залежність коефіцієнта трансформації і максимального прискорюючого поля від довжини згустку при незмінному заряду згустку. Враховувалося, що довжина нелінійної кільватерної хвилі збільшується зі збільшенням довжини згустку. Показано, що коефіцієнт трансформації досягає максимального значення при деякої довжині згустку. Максимальне значення коефіцієнта трансформації досягає шести як за рахунок профілювання згустку, так і за рахунок нелінійності кільватерної хвилі.

КЛЮЧОВІ СЛОВА: коефіцієнт трансформації, кільватерне поле в плазмі, нелінійне кільватерне поле, прискорення кільватерним полем

\section{ЗАВИСИМОСТЬ КОЭФФИЦИЕНТА ТРАНСФОРМАЦИИ ОТ ДЛИНЫ СГУСТКА ПРИ ВОЗБУЖДЕНИИ НЕЛИНЕЙНОЙ КИЛЬВАТЕРНОЙ ВОЛНЫ В ПЛАЗМЕ ЭЛЕКТРОННЫМ СГУСТКОМ С НАРАСТАЮЩИМ ЗАРЯДОМ ПО ГАУССУ \\ Д.С. Бондарь ${ }^{2}$, И.П. Левчук ${ }^{1}$, В.И. Маслов ${ }^{1,2}$, И.Н. Онищенко ${ }^{1}$ \\ ${ }^{1}$ ННЦ Харьковский физико-технически институт 61108, Харьков, Украина \\ ${ }^{2}$ Харьковский начиональный университет имени В.Н. Каразина 61022, Харьков, Украина}

Используя код LCODE, проведено $2 \mathrm{~d} 3 \mathrm{v}$ численное моделирование возбуждения нелинейной кильватерной волны в плазме профилированным релятивистским электронным сгустком с плотностью заряда, нарастающей по закону Гаусса до максимального значения, а потом резко обрывающегося до нуля. Коэффициент трансформации, как отношение максимального ускоряющего поля к максимальному тормозящему полю внутри сгустка, и ускоряющее поле исследованы с учетом нелинейности кильватерной волны. Исследована зависимость коэффициента трансформации и максимального ускоряющего поля от длины сгустка при неизменном заряде сгустка. Учитывалось, что длина нелинейной кильватерной волны увеличивается с увеличением длины сгустка. Показано, что коэффициент трансформации достигает максимального значения при некоторой длине сгустка. Максимальное значение коэффициента трансформации достигает шести как за счет профилирования сгустка, так и за счет нелинейности кильватерной волны.

КЛЮЧЕВЫЕ СЛОВА: коэффициент трансформации, кильватерное поле в плазме, кильватерный пузырь, нелинейное кильватерное поле, ускорение кильватерным полем 
The wakefield excitation in a plasma and its application for particle acceleration avoids the problem of breakdown in the metal structures of accelerators when fields exceeded the value $100 \mathrm{MV} / \mathrm{m}$ and creates accelerating gradients which are of considerably (three orders) higher intensity [1-6].

The efficiency of electron acceleration by a wakefield excited in a plasma by a sequence of electron bunches is determined by the transformer ratio (TR) [7-29]. The transformer ratio is the ratio of energy acquired by the witness to energy lost by the driver. Approximately, the transformer ratio can be defined as $T R=E_{a c} / E_{d e c}$. Where $E_{a c}$ is the maximum accelerating field after the driver bunch (at the end of the first or second bubble). And $E_{\text {dec }}$ is the maximum decelerating field inside driver bunch.

Earlier in [13] it was shown that in the linear case, using an Gaussian bunch, the transformer ratio does not exceed $\mathrm{TR} \leq 2$.

In this work, using a non-linear version of the $2 \mathrm{~d} 3 \mathrm{v}$ code lcode, numerical simulation of excitation of a non-linear (blowout or bubble mode) wakefield in a plasma by a shaped relativistic electron bunch was performed. Also, the transformer ratio was investigated. In a shaped electron bunch, the charge density along it in the longitudinal direction increases approximately in Gaussian (by cosine) from a zero to maximum, and then abruptly breaks off. The dependence of the accelerating field and TR on the length of the bunch $\xi_{\mathrm{b}}$ is studied when the bunch length $\xi_{\mathrm{b}}$ changes from 0 to the length of the nonlinear wake (bubble), $0<\xi_{b}<\lambda_{N L} \approx 2 \lambda$. Here $\lambda$ is the linear wavelength. It is taken into account that the length of the nonlinear wakefield increases when the length of the bunch increases. In a strongly nonlinear regime, this problem cannot be solved analytically. Therefore, it was investigated using a nonlinear version of the code lcode with a constant charge of the bunch.

For numerical simulation parameters have been selected: relativistic factor of bunch equals $\gamma_{b}=1000$. The electron plasma frequency is $\omega_{\mathrm{pe}}=\left(4 \pi \mathrm{n}_{\mathrm{r}} \mathrm{e}^{2} / \mathrm{m}_{\mathrm{e}}\right)^{1 / 2}$. We consider the bunch, electrons in which are distributed according to Gaussian in the transverse direction along the radius. $\xi=\mathrm{V}_{\mathrm{b}} \mathrm{t}-\mathrm{z}, \mathrm{V}_{\mathrm{b}}$ is the bunch velocity. Time is normalized on $\omega_{\mathrm{pe}}{ }^{-1}$, distance - on $\mathrm{c} / \omega_{\mathrm{pe}}$, density - on $\mathrm{n}_{\mathrm{r}}$, current $\mathrm{I}_{\mathrm{b}}-$ on $\mathrm{I}_{\mathrm{cr}}=\pi \mathrm{mc}^{3} / 4 \mathrm{e}$, fields - on $\left(4 \pi \mathrm{n}_{\mathrm{r}} \mathrm{c}^{2} \mathrm{~m}_{\mathrm{e}}\right)^{1 / 2}$.

We use the cylindrical coordinate system $(\mathrm{r}, \mathrm{z})$ and draw the plasma and beam densities and longitudinal electric field at some $\mathrm{z}$ as a function of the dimensionless time $\tau=\omega_{\mathrm{p}} \mathrm{t}$.

The longitudinal coordinate $\xi=z-V_{b} t$ is normalized on $\lambda / 2 \pi$. The values of the $E_{z}, F_{r}$ and $H_{\theta}$ are normalized on mc $\omega_{\mathrm{pe}} / \mathrm{e}$. Where e, $\mathrm{m}$ are the charge and mass of the electron, $\mathrm{c}$ is the light velocity, $\omega_{\mathrm{pe}}$ is the electron plasma frequency.

We do not take into account the longitudinal dynamics of the bunches, because at the times and energies of the beam according to

$$
\frac{\mathrm{dV}_{\mathrm{z}}(\mathrm{r})}{\mathrm{dr}} \propto \frac{1}{\gamma_{\mathrm{b}}^{3}}, \frac{\mathrm{dV}_{\mathrm{r}}(\mathrm{r})}{\mathrm{dr}} \propto \frac{1}{\gamma_{\mathrm{b}}}
$$

radial relative shifts of beam particles predominate. $\mathrm{V}_{\mathrm{z}}, \mathrm{V}_{\mathrm{r}}$ are the longitudinal and radial velocities of the electron bunches, $\gamma_{b}$ is the relativistic factor of the bunch.

The aim of the paper is the demonstration by the numerical simulation that the transformer ratio - an important value in the wakefield method of acceleration of electron bunches, can be increased by a factor of three due to the profiling of the electron-driver-bunch and due to the non-linearity of the excited wakefield.

\section{INVESTIGATION OF THE TRANSFORMER RATIO}

We consider wakefield excitation in the plasma by the bunch near the injection boundary, since the bunch is deformed when the penetration into the plasma is deep. The main purpose of this work - to consider factors which can increase the transformer ratio when the bunch excites wakefield in plasma. It is also an important task to search for the optimal length of the bunch to obtain the highest transformer ratio. bubble.

In Fig. 1 the dependence of the value of the transformer ratio on the bunch length is shown for the case of the first

The value of the transformer ratio increases almost linearly with increase of the length of the bunch, until the length of the bunch reaches $1.125 \lambda$. But then after a local maximum at a bunch length of $1.125 \lambda$ the transformer ratio increases with bunch length increase. The largest value of the transformer ratio is achieved when the bunch length equals $7 \lambda / 4$. I.e. the largest transformer ratio is achieved through the interval of the length of the bunch, approximately equal $\lambda / 2$. One can see in Fig. 1 that the transformer ratio reaches maximum value $\mathrm{TR}^{1 \mathrm{st}} \approx 5.25$ when the bunch length equals to $7 \lambda / 4$ for the first bubble in the nonlinear regime for profiled bunch. Further increase of a bunch length leads to a decrease of the transformer ratio.

Thus, we can state that the length of the bunch $7 \lambda / 4$ is the optimal length from the point of view of the efficiency of electron acceleration by the excited wakefield, namely by the wakefield at the end of the first wake bubble. $\lambda$ is the wavelength of the linear wakefield.

Further, we consider the transformer ratio for the second bubble. One can see in Fig. 1 that in this case the transformer ratio behaves in a similar way, as in the case of the first bubble. First, TR increases almost linearly with increasing of the length of the bunch, until the bunch length reaches the value of $3 \lambda / 4$. After that one can see the maximum when the length of the bunch reaches $7 \lambda / 4$ (the interval from the first maximum is $\lambda$ ). When the length of the 
bunch reaches $1.125 \lambda$, in the both cases of the first and the second bubble, small (relative to the main maximum) jump of the value of the transformer ratio is observed.

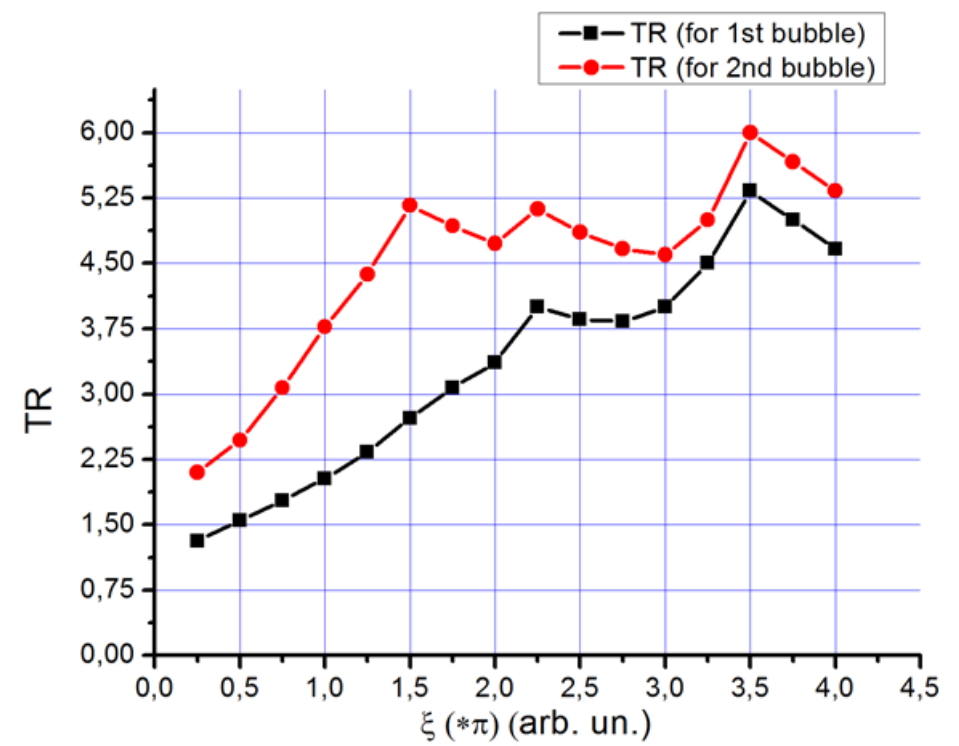

Fig. 1. Dependence of the transformer ratio on the length of the bunch for the 1st and 2nd bubble (normalized by the wavelength of a linear wakefield)

Further, after the TR maximal value at length of the bunch $7 \lambda / 4$ the transformer ratio decreases. For the second bubble, the maximum transformer ratio for the bunch length $7 \lambda / 4$ is equal to $\mathrm{TR}^{2 \mathrm{nd}} \approx 6.00$. For the subsequent (after the first) bunches, the transformer ratio can increase at certain conditions. This can occur due to the accumulation (summation) of the wakefield at approximately the same the decelerating field for all bunches.

Moreover, it is remarkable that the maximums of the transformer ratio are observed at the same length of the bunch after the first and the second bubbles. This leads to the possibility to accelerate two bunches: one bunch at the end of the first bubble, and the second bunch at the end of the second bubble, placing them to the maximum accelerating fields at the bunch length equal to $7 \lambda / 4$.

\section{INVESTIGATION OF THE ACCELERATING AND DECELERATING FIELDS}

Further, the dependence of the accelerating field from the length of the bunch in the nonlinear regime was studied for the shaped driver-bunch (Fig. 2). It is observed that the amplitude of the excited nonlinear wakefield decreases (in absolute value) when the length of the bunch increases, similarly to the case of a linear wakefield with an unformed bunch investigated by other authors [7].

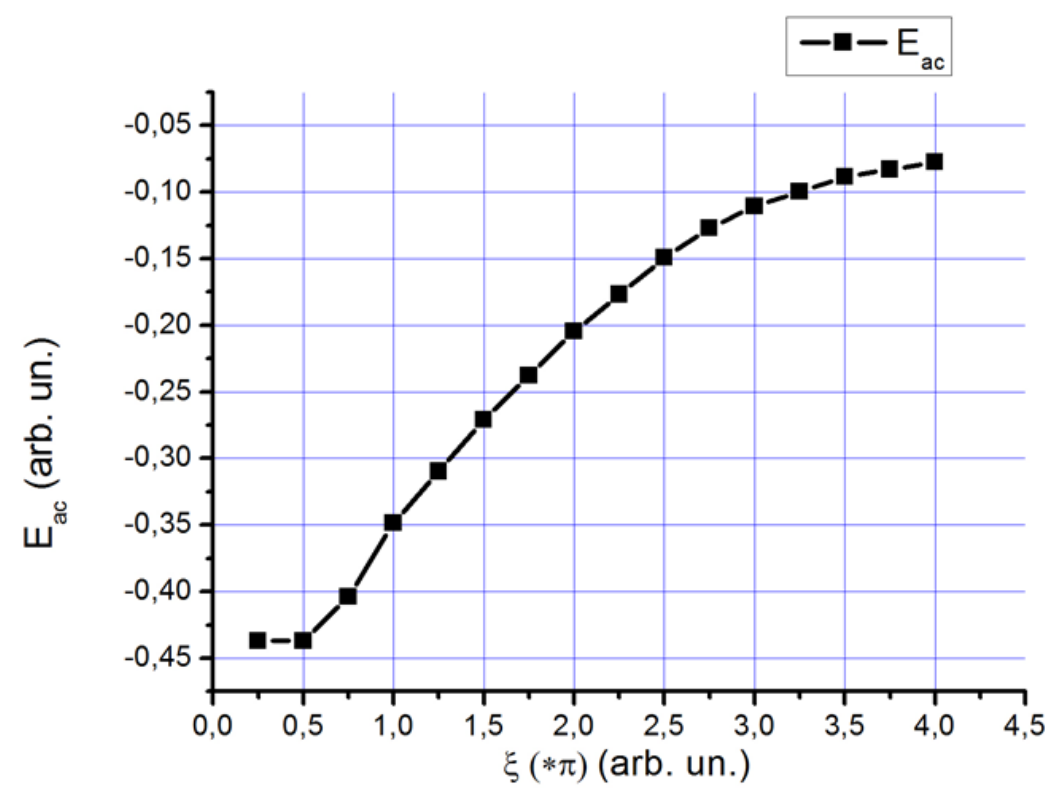

Fig. 2. Dependence of the accelerating field on the length of the bunch for the 1st bubble. 
This is determined by the finite length of the considered bunch. Indeed, each point of the bunch excites a field whose distribution can be approximately described by a semi-cosine. However, since the fields are excited at different points, some of them are in antiphase and suppress each other. Therefore, the amplitude of the accelerating field decreases with increasing length of the bunch.

In the case of the second bubble (Fig. 3), a similar dependence is observed: in absolute value, the amplitude of the accelerating field decreases. However, in the case of the second bubble, the amplitude of the accelerating field is initially larger than the amplitude of the accelerating field in the case of the first bubble. Strictly speaking, this leads to an increase of the maximum value of the transformer ratio in the case of the second bubble. The excess of the maximum accelerating field after the second bubble over the accelerating field after the first bubble can be explained by the inertness of the plasma electrons, which received a pulse from the driver bunch; and by influence of the space charge of the driver bunch.

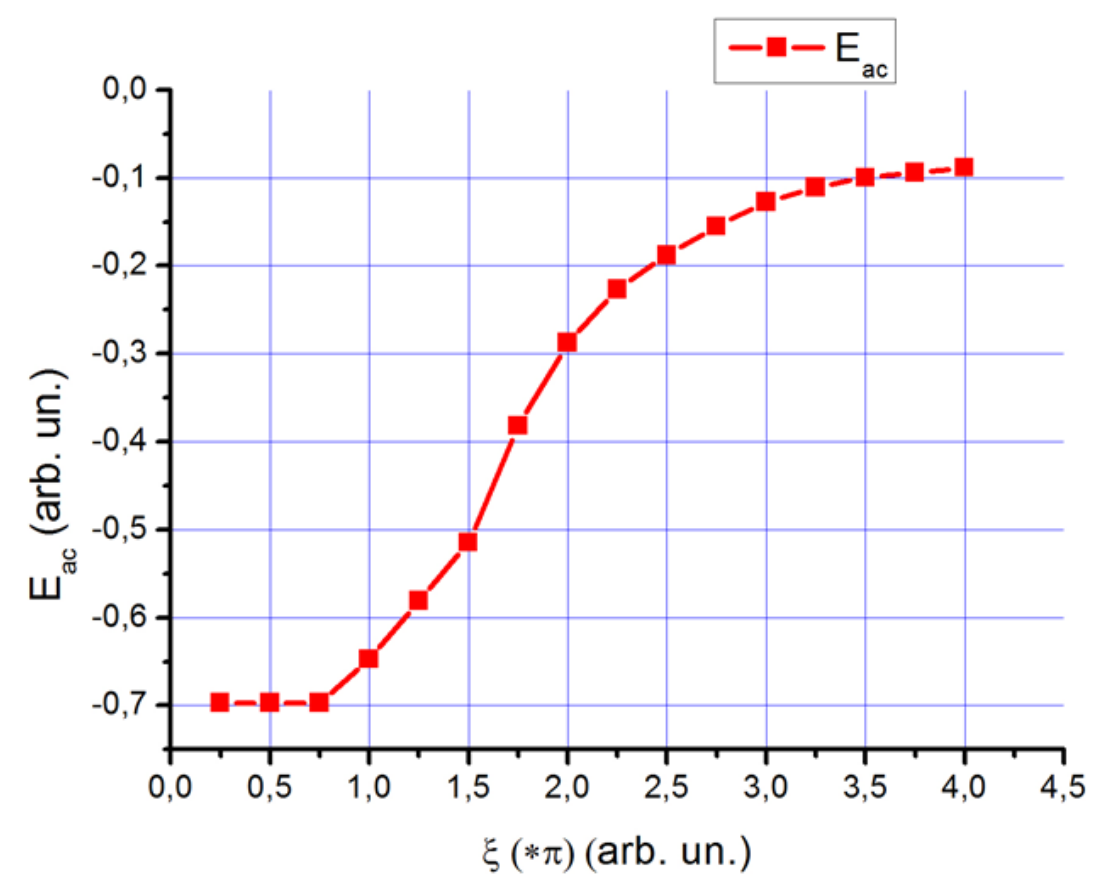

Fig. 3. Dependence of the accelerating field on the length of the bunch for the 2nd bubble.

In our case, when the length of the bunch increases with a fixed charge of the bunch, i.e. with a fixed number of electrons in the bunch, when electron density in the bunch $n_{b}$ decreases, the bubble lengthens Fig. 4. (a) (b)

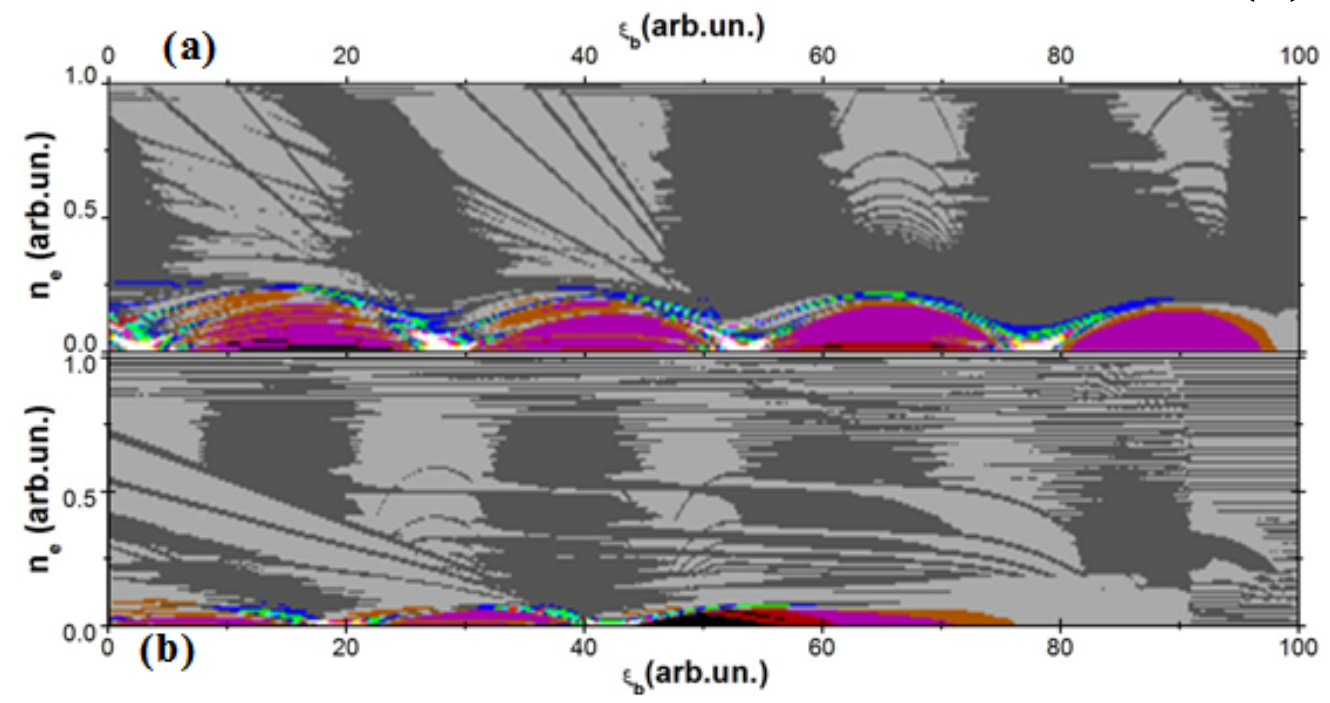

Fig. 4. Spatial distribution of the density of plasma electrons.

The figure above (a) is for a bunch length equal to $0.25^{*} \pi$. The figure below (b) is for the length of the bunch, equal to $3.75^{*} \pi$.

In addition, the dependence of the decelerating field on the length of the bunch was investigated (Fig. 5). 
One can see from Fig. 5 that the dependence of the decelerating field on the length of the bunch is a function that decreases monotonically with increasing of the length of the bunch.

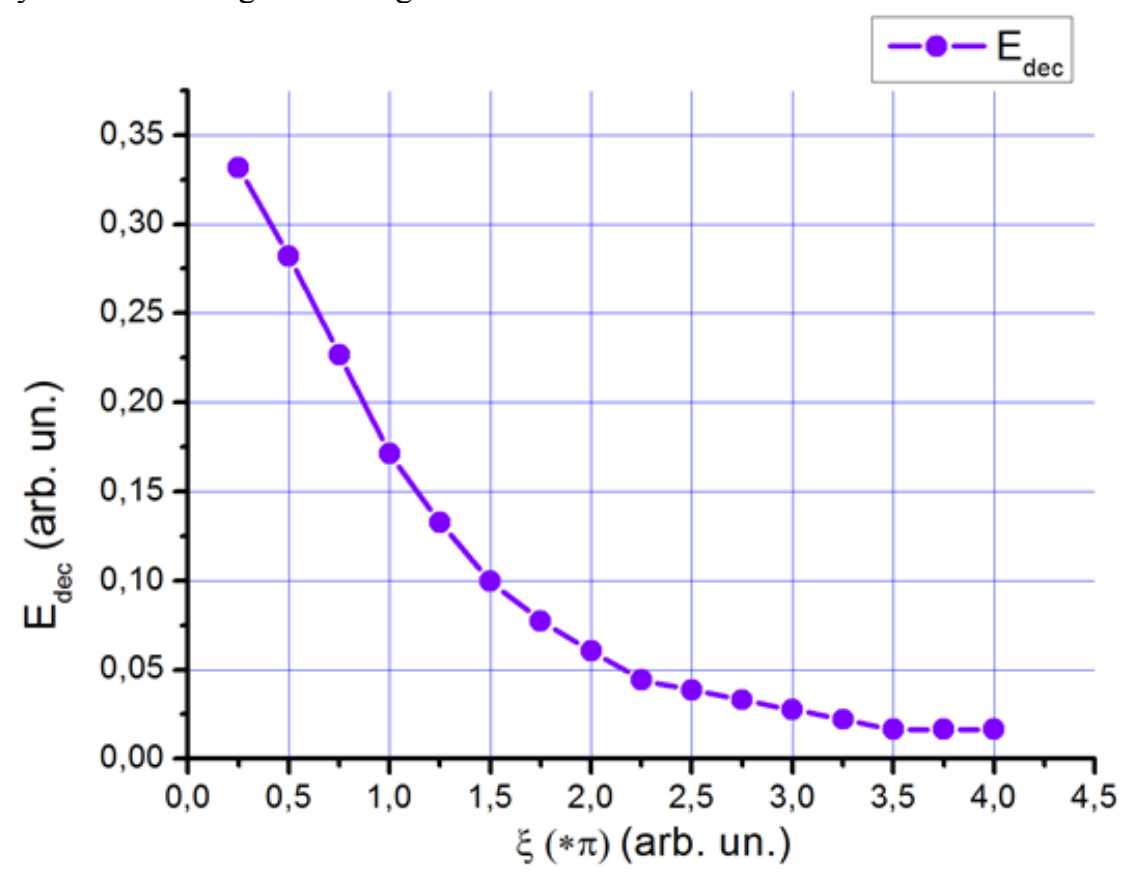

Fig. 5 Dependence of the decelerating field on the length of the bunch

\section{CONCLUSION}

Thus, we can state the following. In this paper, it was demonstrated by numerical simulation that the transformer ratio at the wakefield excitation by a bunch of relativistic electrons increases due to the profiling of the bunch, and also due to the nonlinearity of the excited wakefield. The value of the transformer ratio after the second bubble exceeds the transformer ratio after the first bubble. It is shown that for certain values of the length of the bunch, the transformer ratio reaches a maximum value exceeding the transformer ratio in the linear case in the absence of shaping of the bunch. The dependence of the accelerating and decelerating fields on the length of the bunch were also investigated and they were established that the obtained dependences agree with the theoretical assumptions.

\section{REFERENCES}

1. Leemans W.P., Gonsalves A.J., Mao H.-S. et al. Multi-GeV Electron Beams from Capillary-Discharge-Guided Subpetawatt Laser Pulses in the Self-Trapping Regime // Phys. Rev. Lett. - 2014. - Vol. 113. - P. 245002.

2. Pukhov A., Meyer-ter-Vehn J. Laser wake field acceleration: the highly non-linear broken-wave regime // Applied Physics B. 2002. - Vol.74. - P. 355-361.

3. Leemans W. P., Nagler B., Gonsalves A. J., Tóth Cs., Nakamura K., Geddes C.G.R., Esarey E., Schroeder C. B., Hooker S.M. GeV electron beams from a centimetre-scale accelerator // Nature Physics. - 2006. - Vol. 2. - P. 696-699.

4. Malka V. Laser plasma accelerators // Phys. of Plasmas. - 2012. - Vol. 19. - P.055501.

5. Hooker S.M., Bartolini R., Mangles S.P.D., Tünnermann A., Corner L., Limpert J., Seryi A., Walczak R. Multi-pulse laser wakefield acceleration: a new route to efficient, high-repetition-rate plasma accelerators and high flux radiation sources // Special Issue of J. Phys. B. - 2014. - Vol. 47. - P 234003.

6. Lotov K.V., Maslov V.I., Onishchenko I.N., Svistun E. Resonant excitation of plasma wakefields by a nonresonant train of short electron bunches // Plasma Phys. Control. Fusion. - 2010. - Vol.52. - No.6. - P. 065009.

7. Jing C., Power J., Zholents A. Dielectric Wakefield Accelerator to Drive the Future FEL Light Source // ANL/APS/LS326. - 2011.

8. Maslov V.I., Onishchenko I.N., Yarovaya I.P. Transformer ratio at excitation of nonlinear wakefield in plasma by shaped sequence of electron bunches with linear growth of charge // VANT. - 2012. - Vol.4.-No.80 - P.128-130.

9. Baturin S. S., Zholents A. Upper limit for the accelerating gradient in the collinear wakefield accelerator as a function of the transformer ratio // Phys. Rev. ST Accel. Beams. - 2017. - Vol.20. - P.061302.

10. Tajima T. Laser acceleration in novel media // Eur. Phys. J. Special Topics. - 2014. - Vol. 223. - No.6. - P. 1037-1044.

11. Massimo F., Marocchino A., Ferrario M., Mostacci A., Musumeci P., Palumbo L. Transformer ratio studies for single bunch plasma wakefield acceleration // Nucl. Inst. and Meth. A. - 2014. - Vol.740. - P.242-245.

12. Jing C., Power J.G., Conde M., Liu W., Yusof Z., Kanareykin A., Gai W. Increasing the transformer ratio at the Argonne wakefield accelerator // Phys. Rev. ST Accel. Beams. - 2011. - Vol. 14. - P. 021302.

13. Wilson P.B. Wake Field Accelerators // Invited talk presented at the SLAC Summer Institute on Particle Physics, Stanford, California. - 1985. - P.1-45.

14. Chen P., Spitkovsky A., Katsouleas T., Mori W.B. Transformer ratio and pulse shaping in laser wakefield accelerator // Nuclear Instruments and Methods in Physics Research Section A: Accelerators, Spectrometers, Detectors and Associated Equipment. - 
1998. - Vol. 410. - No.3. - P. 488-492.

15. Spitkovsky A., Chen P. Longitudinal laser shaping in laser wakefield accelerators // Phys. Lett. A. - 2002. - Vol. 296. - No.2. P. $125-130$.

16. Leemans W.P., Catravas P., Esarey E., Geddes C.G.R., Toth C., Trines R., Schroeder C.B., Shadwick B.A., Tilborg van J., Faure J. Electron-Yield Enhancement in a Laser-Wakefield Accelerator Driven by Asymmetric Laser Pulses // Phys. Rev. Lett. - 2002. - Vol. 89. - No. 17. - P. 174802.

17. Maslov V.I., Onishchenko I.N., Yarovaya I.P. Transformation Ratio at Excitation of Nonlinear Wakefield in Plasma by Shaped Sequence of Electron Bunches with Linear Growth of Charge // Problems of Atomic Science and Technology. - 2012. - Vol.4. -No. 80. - P.128-130.

18. Jiang B., Jing C., Schoessow P., Power J., Gai W. Formation of a novel shaped bunch to enhance transformer ratio in collinear wakefield accelerators // Phys. Rev. ST Accel. Beams 15. - 2012. - P. 011301.

19. Maslov V.I., Onishchenko I.N., Yarovaya I.P. Wakefield Excitation in Plasma by Sequence of Shaped Electron Bunches // Problems of Atomic Science and Technology. Ser. Plasma Physics. - 2012. - No.6. - P. 161-163.

20. Lemery F., Piot P. Tailored electron bunches with smooth current profiles for enhanced transformer ratios in beam-driven acceleration // Phys. Rev. ST Accel. Beams 18. - 2015. - P. 081301.

21. Maslov V.I., Onishchenko I.N. Transformation Ratio at Wakefield Excitation in Dielectric Resonator by Shaped Sequence of Electron Bunches with Linear Growth of Current // Problems of Atomic Science and Technology. Problems of Atomic Science and Technology. - 2013. - Vol.4. - No.86. - P. 69-72.

22. Altmark A.M., Kanareykin A.D. Annular Cherenkov high gradient wakefield accelerator: beam-breakup analysis and energy transfer efficiency // Journal of Physics: Conference Series. - 2012. - Vol.357. - P.012001.

23. Maslov V.I., Onishchenko I.N. Transformation Ratio at Wakefield Acceleration in Dielectric Resonator // Problems of Atomic Science and Technology. Ser. Nuclear Physics Investigations. - 2014. - Vol.3. - P. 99-101.

24. Balakirev V.A., Onishchenko I.N., Sotnikov G.V., Fainberg Ya.B., Charged particle acceleration in plasma by wakefield of shaped train of relativistic electron bunches // Sov. Plasma Phys. - 1996. - Vol. 22. - No.2. - P.157-164.

25. Maslov V.I., Onishchenko I.N. Transformation Ratio at Wakefield Excitation in Dielectric Resonator by Sequence of Rectangular Electron Bunches with Linear Growth of Charge // Problems of Atomic Science and Technology. Ser. Nuclear Physics Investigations. - 2014. - No.3. - P.95-98.

26. Nakajima K. Plasma Wake-field Accelerator Driven by a Train of Multiple Bunches // Particle Accelerators. 1990. Vol.32. - P.209-214.

27. Maslov V.I., Svistun O.M. Transformation Ratio at Plasma Wakefield Excitation by Laser Pulse with Ramping of its Intensity according to Cosine // East Eur. J. Phys. - 2014. - Vol.1. - No.4. - P. 84-87.

28. Kazakov S.Yu., Kuzikov S.V., Jiang Y., Hirshfield L. High-gradient two-beam accelerator structure // Phys. Rev. ST Accel. Beams. - 2010. - Vol. 13. - P. 071303.

29. Levchuk I.P., Maslov V.I., Onishchenko I.N. Transformation Ratio at Wakefield Excitation by Linearly Shaped Sequence of Short Relativistic Electron Bunches // Problems of Atomic Science and Technology. - 2015. - No.6. - P. 37-41. 